Original Article

\title{
The effect of NPK 16-6-23 fertilizer dosage on the growth and yield of the rice Inpari 30 in Bangkalan regency, East Java
}

\author{
Lina Aisyawati*\#, Fuad Nur Azis", Winda Syafitri", Ratih Kusumasari Ndarü, Evy Latifah ${ }^{\#}$ \\ Assessment Institute for Agricultural Technology (AIAT) of East Java, Ministry of Agriculture, Indonesia
}

\begin{abstract}
Comprehensive site-specific fertilization dose is an essential factor to increase crop production. Fertilizer dose application should be based on the nutrient content in soil and plant, type and quality of fertilizer, and the climate. This study was aimed to determine the effect of unbalanced compound fertilizer NPK 16-6-23 at various doses to rice crops' growth and yield Inpari 30 in Bangkalan regency. This research was conducted from June to October 2016. The rice varieties were Inpari 30 planted with legowo 2: 1 row system. The study used 8 different treatments : (1) without fertilizer, (2) standard dose of $200 \mathrm{~kg} / \mathrm{ha}$ Urea and $300 \mathrm{~kg} / \mathrm{ha} \mathrm{NPK} \mathrm{15-15-15,} \mathrm{(3)} 200 \mathrm{~kg} / \mathrm{ha} \mathrm{NPK} \mathrm{16-6-23,} \mathrm{(4)} \mathrm{300} \mathrm{kg/ha} \mathrm{NPK} \mathrm{16-6-23,} \mathrm{(5)} \mathrm{400} \mathrm{kg/ha} \mathrm{NPK} \mathrm{16-6-23,}$ (6) $200 \mathrm{~kg} / \mathrm{ha}$ Urea + $200 \mathrm{~kg} / \mathrm{ha}$ NPK 16-6-23, (7) $200 \mathrm{~kg} / \mathrm{ha}$ Urea $+300 \mathrm{~kg} / \mathrm{ha} \mathrm{NPK} \mathrm{16-6-23,} \mathrm{and} \mathrm{(8)} 100 \mathrm{~kg} / \mathrm{ha}$ Urea + 400 kg/ha NPK 16-6-23. The study used a randomized complete block design with 3 replications. The parameters were observed by plant height, number of productive tillers, panicle length, number of grain per panicle, number of filled and empty grain per panicle, percentage of filled grain, 1000 seed weight, and productivity. The results showed that $200 \mathrm{~kg} / \mathrm{ha}$ Urea $+300 \mathrm{~kg} / \mathrm{ha}$ NPK $16-6-23$ produced the highest plant growth on 50 DAP $(77.83 \mathrm{~cm})$, a low number of empty grain (11.84), a high percentage of filled grain $(90.7 \%)$, and high production $(7.29$ t/ha). This treatment has agronomically higher effectiveness compared to standard doses with RAE value of $196.61 \%$. This fertilizer dose is highly recommended for farmers to increase Inpari 30 rice crops in Bangkalan.
\end{abstract}

Keywords: NPK fertilizer, Inpari 30 rice field, fertilization recommendation, Bangkalan

Received: 30 October 2020 Revised: 26 December 2020 Accepted: 31 December 2020

\section{Introduction}

Fertilization technology is one of the decisive factors to increase crop production. Rational and appropriate fertilizer standards must be fulfilled and adapted to specific locations. For example, nutrient levels in the soil, nutrients needed by plants, types, quality of fertilizers, and climatic conditions should be considered to obtain the optimum crop production. In line with developments and advances in fertilization technology and soil nutrient status changes, the existing fertilization standards should be further observed and refined (Putra, 2012).

Efforts should be optimized to increase the fertilizer efficiency, including the dosage of fertilizers, the method of application, and the proper form of fertilizers. The application of inorganic fertilizers through the soil can reduce fertilization efficiency and disturb the balance of nutrients if the application time and dose are not appropriate (Azis et al., 2018). The types of fertilizers can be used in the single form of fertilizers, compound fertilizers, or a mixture of both ingredients. The compound fertilizers facilitated the nutrient access for plants (Hartatik \& Widowati, 2015). NPK compound is one of the fertilizers that commonly used by rice farmers. This fertilizer contains N, P, and K elements, which are essential nutrients for plants (Kasno \& Setyorini, 2008). NPK 15- 15-15 is the common NPK fertilizer used by farmer Currently, there are many new types of NPK

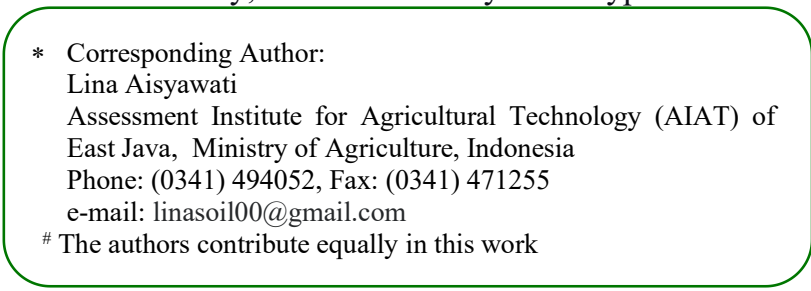

http://dx.doi.org/10.23869/bphjbr.26.1.20208

Published by (C) PBI East Java. Open Access www.berkalahayati.org fertilizers circulating with an unbalanced composition of $\mathrm{N}$, $\mathrm{P}$, and $\mathrm{K}$ elements that needed for further observation against plants.

Nitrogen $(\mathrm{N})$ is the most essential nutrient for vegetative plant growth (Marchezan et al., 2020). The nitrogen induces the plant growth and carbohydrate and protein metabolism. The higher dose of nitrogen fertilizer, the faster process the synthesis of carbohydrates into protein and protoplasm. However, the application of $\mathrm{N}$ fertilizers is often inefficient due to $30 \%$ of the $\mathrm{N}$ element in the applied fertilizer can be absorbed by the plants, while the rest is lost through volatilization, denitrification, leaching, and runoff. In Indonesia, it is estimated that $52-71 \%$ loss of $\mathrm{N}$ elements come from agricultural land (Abdulrachman et al., 2009).

The phosphorus (P) is the second essential nutrient for plant growth. The amount of phosphorus in minerals is more significant than nitrogen. However, almost all phosphorus in the soil is not available to plants due to fixation by $\mathrm{Al}, \mathrm{Fe}, \mathrm{Ca}$, and $\mathrm{Mg}$ (Malhotra et al., 2018). Another element that essential for plants is potassium. Potassium $(\mathrm{K})$ is required to mould carbohydrates and proteins metabolism, photosynthesis processes, catalysts and capacitors of complex compounds, and accelerators of enzyme activities. The $\mathrm{K}$ content in plants is often excessive than the number of plant needs. The application of unbalanced $\mathrm{N}, \mathrm{P}$, and $\mathrm{K}$ fertilization can affect rice productivity (Huang et al., 2008).

In addition to fertilization technology, Juanda (2009) reported that superior varieties also play an essential role to increase national rice production, reaching $56 \%$. The new superior variety (VUB) of rice widely used is Inpari 30 Ciherang Sub 1, which was released in 2012 (based on the Decree of the Minister of Agriculture: 2292.1/ 
Kpts/SR.120/6/2012 dated 27 June 2012). This variety is one type of irrigated rice field with the following characters: plant age 111 days, the average yield of 7.2 $\mathrm{t} / \mathrm{ha}$ with yield potential up to $9.6 \mathrm{t} / \mathrm{ha}$, and susceptible to brown planthoppers and bacterial leaf blight in some extents. This variety is suitable for planting in irrigated rice fields at an altitude of up to $400 \mathrm{~m}$ above sea level, in river overflows, basins, and is prone to flooding with the immersion of the entire vegetative phase for 15 days (Jamil et al., 2015).

Bangkalan Regency is one of the potential areas for rice development in East Java Province. According to the East Java Central Bureau of Statistics (2016), in the last five years, rice production has increased in 2012, 2014, and 2015 , but decreased by $0.13 \%$ in 2016 . Briefly, a significant increase occurred in 2012, from 10.58 million tons to 12.20 million tons (15.34\%), 2014 (2.98\%) and 2015 (6.11\%). However, in 2016, the decline of rice production was occurred in East Java by $5.98 \%$, but not in Bangkalan Regency, where rice production consistently increased by $6.74 \%$ each year with average productivity of 5.86 tonnes/ha. The increase of rice production in Bangkalan needs to be maintained and further enhanced with various renewal efforts, including fertilizers with the appropriate dose. Therefore, this study aims to determine the effect of NPK fertilizer dosage 166-23 on the growth and yield of lowland rice in Bangkalan Regency.

\section{Method}

The research was conducted in Gili Timur Village, Kamal District, Bangkalan Regency, Bangkalan Regency from June to October 2016. The rice varieties used were Inpari 30 rice with a planting age of 15 days after seeding and planted using the "Jajar Legowo 2:1 system using a randomized block design with 8 treatments as shown in Table 1. The treatment was the combination of Urea, Phonska and NPK 16-6-23 with 3 replications.

The treatment plots were $6 \mathrm{~m} \times 6 \mathrm{~m}$ in size. Treatment without fertilizer is the treatment without giving fertilizer which is tested in accordance with the guidelines for Inorganic Fertilizer Effectiveness Test, according to Suriadikarta et al. (2004). The standard fertilization treatment is the fertilizer treatment for lowland rice according to the general recommendation for balanced fertilization using NPK 15-15-15 fertilizer (200 kg Urea + $300 \mathrm{~kg}$ NPK 15-15-15).

The soil was randomly (composite) sampled at 10 point sites and analyzed at the Soil Laboratory of the East Java Agricultural Technology Research Institute. Basic soil analysis parameters include $\mathrm{pH}, \mathrm{C}$-organic, total N, P2O5, CEC value, soil texture.

The parameter observations include plant height measurement at 50 Day After Planting (DAP) and before harvesting (110 DAP), the number of productive tillers before harvesting, panicle length, number of filled grains per panicle, number of empty grains per panicle, percentage of filled grain, the weight of 1000 seeds, and a yield after harvest. The data were further analyzed using the $\mathrm{F}$ test with an error level of $5 \%$. The significantly different variables were further tested using the Tukey's Honestly Significant Difference (Tukey's HSD) of 5\% (Gomez \& Gomez, 2007). Treatment effectiveness is calculated using the RAE (Relative Agronomic Effectiveness) value, according to Sudiakarta et al. (2004).

$$
\begin{aligned}
& \mathrm{RAE}=\frac{\text { new fertilizer yield }- \text { yield without fertilizer }}{\text { recommendation fertilizer results }- \text { yield without fertilizer }} \times 100 \% \\
& \text { Note } \\
& \text { RAE : the relative agronomic effectiveness }
\end{aligned}
$$

\section{Analysis of farming costs}

Analysis of farming costs is the excitement of farmers' costs in one planting period consisting of fixed costs and variable costs. Fixed costs represent all costs incurred by farmers. These two costs add up to the total cost. According to (Soekartawi, 2002), the formula for calculating total costs includes:

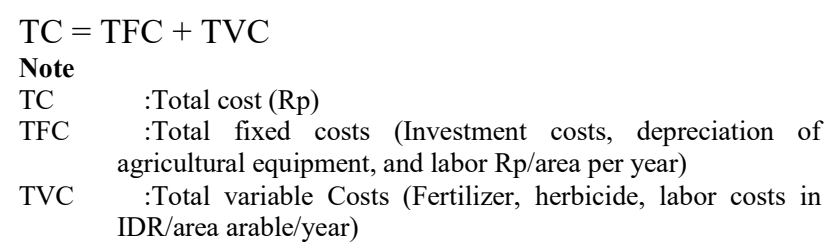

The analysis of farm income obtained by farmers can be calculated from the production results multiplied by farmers' price of products. Meanwhile, farmer revenue is the total revenue minus the costs incurred by the farmer.

$\begin{array}{ll}\Pi=\text { TR-TC } \\ \text { Note } & \\ \Pi & \text { :Farm income } \\ \text { TR } & \text { :Total receipts } \\ \text { TC } & \text { :Total cost }\end{array}$

Fertilization farming analysis for lowland rice is under general recommendations for balanced fertilization using NPK 15-15-15 fertilizer (200 kg Urea + $300 \mathrm{~kg}$ NPK 15-15-15). R/C Ratio (Revenue-Cost Ratio) to determine the ratio of the level of profit and farming cost $\mathrm{R} / \mathrm{C}$ Ratio $=$ Revenue Cost. So it can be interpreted that if the $\mathrm{R} / \mathrm{C}$ ratio is $>1$, farming is profitable, while the $\mathrm{R} / \mathrm{C}$ ratio $<1$ is said to be detrimental because the costs incurred are greater than the revenue earned.

The data obtained will be analyzed using the partial budget analysis method (Soha, 2014) as follows:
dNI : dTR - dVC
$\mathrm{R} \quad: \mathrm{dNI} / \mathrm{dVC}$

$\begin{array}{ll}\text { Note } & \\ \text { dNI } & \text { :Marginal net income } \\ \text { dTR } & \text { :Marginal total revenue } \\ \text { dVC } & \text { :Costs change marginally } \\ \text { R } & \text { :Marginal rate of return } \\ & \\ \text { The decisions can be made: } \\ \text { R }<1: \text { Treatment does not provide added value } \\ \mathrm{R}>1: \text { Treatment provide added value }\end{array}$




\begin{tabular}{|c|c|c|c|c|}
\hline \multirow[t]{2}{*}{ No } & \multirow[t]{2}{*}{ Treatment } & \multicolumn{3}{|c|}{ Dose (kg/ha) } \\
\hline & & Urea & NPK 15- & NPK 16-6- \\
\hline 1 & A (Control) & 0 & 0 & 0 \\
\hline 2 & B (standard) & 200 & 300 & 0 \\
\hline 3 & $\mathrm{C}$ & 0 & 0 & 200 \\
\hline 4 & $\mathrm{D}$ & 0 & 0 & 300 \\
\hline 5 & $\mathrm{E}$ & 0 & 0 & 400 \\
\hline 6 & $\mathrm{~F}$ & 200 & 0 & 200 \\
\hline 7 & $\mathrm{G}$ & 200 & 0 & 300 \\
\hline 8 & $\mathrm{H}$ & 100 & 0 & 400 \\
\hline
\end{tabular}

\section{Results}

\section{Basic soil analysis}

The soil observation in Gili Timur Village, Kamal District, and Bangkalan Regency are presented in Table 2. The type of soil texture in the sampling site is clay with a slightly alkaline soil $\mathrm{pH}$. The $\mathrm{pH}$ value of $\mathrm{H} 2 \mathrm{O}$ is greater than the $\mathrm{pH}$ value of $\mathrm{KCl}$, indicating the negative charges of soil which may come from clay minerals. The negative charge causes the soil having a high affinity for binding cations and releasing anions from the sorption complex so that they become available forms. This can also be seen from the very high CEC of the soil.

Table 2. The results of soil testing at the sampling site in Gili Timur Village, Kamal District, Bangkalan Regency

\begin{tabular}{|c|c|c|c|}
\hline No & Test Parameters & Result & Category \\
\hline 1 & $\begin{array}{l}\text { Water content } \\
\mathrm{pH}\end{array}$ & $7.40 \%$ & \\
\hline 2 & $\mathrm{H}_{2} \mathrm{O}$ & 8.1 & $\begin{array}{l}\text { Slightly } \\
\text { alkaline }\end{array}$ \\
\hline & $\mathrm{KCl}$ & 7.22 & \\
\hline 3 & C-Organic (for dry samples & $1.95 \%$ & Low \\
\hline 4 & N-total (for dry samples & $0.11 \%$ & Low \\
\hline 5 & $\begin{array}{l}\mathrm{P}_{2} \mathrm{O}_{5} \text { (for dry samples } \\
\text { Cation exchange rate } \\
\text { (for dry samples } 105^{\circ} \mathrm{C} \text { ) }\end{array}$ & 49 ppm & Very high \\
\hline 6 & $\begin{array}{l}\text { Cations can be measured } \\
(d d) \\
\text { Cation Exchange Capacity } \\
(C E C)\end{array}$ & $\begin{array}{c}0.21 \\
\text { me. } 100 \mathrm{~g}^{-1} \\
41.22 \\
\text { me. } 100 \mathrm{~g}^{-1}\end{array}$ & $\begin{array}{c}\text { Low } \\
\text { Very high }\end{array}$ \\
\hline 7 & Texture & & \\
\hline & - $\quad$ Sand & $17 \%$ & \\
\hline & - Dust & $33 \%$ & \\
\hline & - $\quad$ Clay & $50 \%$ & \\
\hline & $\begin{array}{l}\text { Criteria (triangle texture } \\
-\quad \text { USDA) }\end{array}$ & Clay & \\
\hline
\end{tabular}

Note: The analysis was conducted at Soil Laboratory of East Java AIAT, category based on Hardjowigeno (1995)

\section{The effect of NPK 16-6-23 fertilizer on the growth of rice}

The Effect of NPK 16-6-23 fertilizer application on rice plants' height 50 Day After Planting (DAP) and 110 DAP for Inpari30 rice in Gili Timur Village, Kamal District, Bangkalan Regency was shown in Table 3, while its effect on the number of productive seedlings and length of panicles was shown in Table 4. The result showed that this treatment of $200 \mathrm{~kg} / \mathrm{ha}$ of fertilizer Urea $+300 \mathrm{~kg} / \mathrm{ha}$ NPK 16-6-23 produced the highest plants that were significantly different from the treatment without fertilization. However, this treatment had no significant effect on productive tillers. Fertilization treatment NPK 16-6-23 as much as $300,400 \mathrm{~kg} / \mathrm{ha}$ and $300 \mathrm{~kg}+200 \mathrm{~kg} / \mathrm{ha}$ Urea resulted in low panicle length which was significantly different from other fertilizer dosage treatments.

Table 3. The height of rice plants 50 Day After Planted (DAP)and 110 DAP for Inpari30 rice in Gili Timur Village, Kamal District, Bangkalan Regency

\begin{tabular}{|c|c|c|c|}
\hline \multirow{2}{*}{ No } & \multirow{2}{*}{ Treatments } & \multicolumn{2}{|c|}{ Height of rice } \\
\hline & & 50 DAP & 110 DAP \\
\hline 1 & Without fertilizer & 63.22 & 83.03 \\
\hline 2 & Standard & 68.54 & 89.37 \\
\hline 3 & $200 \mathrm{~kg} / \mathrm{ha}$ NPK 16-6-23 & 73.96 & 92.7 \\
\hline 4 & $300 \mathrm{~kg} / \mathrm{ha}$ NPK 16-6-23 & 70.08 & 90.2 \\
\hline 5 & $400 \mathrm{~kg} / \mathrm{ha}$ NPK 16-6-23 & 74.75 & 91.3 \\
\hline 6 & $\begin{array}{l}200 \mathrm{~kg} / \mathrm{ha} \text { Urea+200 kg/ha NPK 16-6- } \\
23\end{array}$ & 74.54 & 94.27 \\
\hline 7 & $\begin{array}{l}200 \mathrm{~kg} / \mathrm{ha} \text { Urea+300 kg/ha NPK 16-6- } \\
23\end{array}$ & 77.83 & 93.5 \\
\hline 8 & $\begin{array}{l}100 \mathrm{~kg} / \mathrm{ha} \text { Urea+400 kg/ha NPK 16-6- } \\
23\end{array}$ & 74.17 & 93.57 \\
\hline
\end{tabular}

Note: numbers followed by the same letter are not significantly different on HSD 5\%

Table 4. The number of productive tillers and length of panicles of rice Inpari 30 in Gili Timur village, Kamal district, Bangkalan Regency

\begin{tabular}{|c|c|c|c|c|}
\hline No. & Treatments & $\begin{array}{c}\text { The number of } \\
\text { productive tillers }\end{array}$ & $\begin{array}{c}\text { Lengt } \\
\text { of }\end{array}$ & \\
\hline 1 & Without Fertilizer & 6.67 & 26.64 & $\mathrm{a}$ \\
\hline 2 & Standard & 8 & 26.16 & a \\
\hline 3 & $200 \mathrm{~kg} / \mathrm{ha}$ NPK 16-6-23 & 7.33 & 26.82 & a \\
\hline 4 & $300 \mathrm{~kg} / \mathrm{ha}$ NPK 16-6-23 & 9.27 & 23.77 & $\mathrm{~b}$ \\
\hline 5 & $400 \mathrm{~kg} / \mathrm{ha}$ NPK $16-6-23$ & 10.13 & 24.06 & $\mathrm{~b}$ \\
\hline 6 & $\begin{array}{c}200 \mathrm{~kg} / \mathrm{ha} \text { Urea+200 kg/ha } \\
\text { NPK 16-6-23 }\end{array}$ & 8.93 & 27.31 & $\mathrm{a}$ \\
\hline 7 & $\begin{array}{c}200 \mathrm{~kg} / \mathrm{ha} \text { Urea+300 kg/ha } \\
\text { NPK 16-6-23 }\end{array}$ & 9.27 & 24.06 & $\mathrm{~b}$ \\
\hline 8 & $\begin{array}{c}100 \mathrm{~kg} / \mathrm{ha} \mathrm{Urea}+400 \mathrm{~kg} / \mathrm{ha} \\
\text { NPK 16-6-23 }\end{array}$ & 9.13 & 26.91 & $\mathrm{a}$ \\
\hline
\end{tabular}

Effect of NPK 16-6-23 fertilizer on rice paddy yields

The Effect of NPK 16-6-23 Fertilizer on total filled grain per panicle, empty grain per panicle, total grain per panicle, percentage filled grain, and weight of 1000 Inpari 30 grains in Gili Timur Village, Kamal District, Bangkalan Regency was presented in Table 5. The results show that fertilization treatment affects filled and hollow grain, and the percentage of filled grain, but no effect on the amount of grain and weight of 1000 seeds. Fertilization treatment $200 \mathrm{~kg} / \mathrm{ha}$ Urea $+300 \mathrm{~kg} / \mathrm{ha} \mathrm{NPK}$ 16-6-23 ( $\mathrm{G}$ treatment) yields the highest-filled grain compared to other treatments, as shown in Figure 1, while the $400 \mathrm{~kg} / \mathrm{ha}$ NPK 16-6-23 (E treatment) is also produced the high yield. The control treatment without fertilizer application resulted in the yield of milled dry unhulled rice. Both treatments provided the highest yields than other fertilization treatments due to the adequate nutrients supply provided by the fertilizer combination. These adequate nutrients can enhance the soil microorganism to produce the fertile soil and create a better plant growth environment (Fig. 1). 
The $\mathrm{G}$ treatment is more recommended due to its highest RAE value, approximately of $196.61 \%$ (Tab. 6), suggesting that NPK 16-6-23 unbalanced compound fertilizer performed as an agronomic inorganic fertilizer. Its RAE value is more than $100 \%$ higher than control and has the same results as its competitors' standard treatment, NPK 15-15-15. The G treatment also supports plant height growth (Tab. 3), a number of filled grains, and percentage of filled grains (Tab. 5), with the highest value compared to other fertilizer dosage treatments.

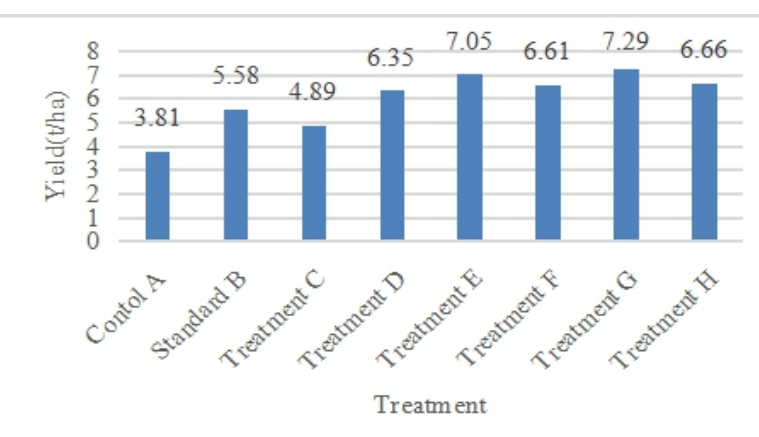

Figure 1. The yield of milled dry unhulled rice ( $t / h$ ha) of rice Inpari 30 in Gili Timur Village, Kamal District, Bangkalan Regency

The results of farm costs and income, and the results of the $\mathrm{B} / \mathrm{C}$ analysis Inpari rice ratio of 30 plants with various combination treatments, are shown in Tables 7 and 8. From tables 7 and 8, the highest income obtained from the application of $\mathrm{G}$ treatment, following the $\mathrm{E}$ treatment. The similar results were also found for the highest $\mathrm{R} / \mathrm{C}$ ratio. Both treatments produce $\mathrm{R} / \mathrm{C}$ ratios are 2.63 and 2.51, respectively. $\mathrm{R} / \mathrm{C}$ Ratio is revenue cost, so it can be interpreted that farming is profitable if the $\mathrm{R} / \mathrm{C}$ ratio $>1$ can be said.
Table 6. The RAE Value on Rice Inpari 30 in Gili Timur Village, Kamal District, Bangkalan Regency.

\begin{tabular}{lc}
\hline \multicolumn{1}{c}{ Treatments } & RAE (\%) \\
\hline Control & - \\
Recommendation & - \\
$200 \mathrm{~kg} / \mathrm{ha} \mathrm{NPK} \mathrm{16-6-23}$ & 61.02 \\
$300 \mathrm{~kg} / \mathrm{ha} \mathrm{NPK} \mathrm{16-6-23}$ & 143.5 \\
$400 \mathrm{~kg} / \mathrm{ha} \mathrm{NPK} \mathrm{16-6-23}$ & 183.05 \\
$200 \mathrm{~kg} / \mathrm{ha} \mathrm{Urea+200} \mathrm{kg/ha} \mathrm{NPK} \mathrm{16-6-23}$ & 158.76 \\
$200 \mathrm{~kg} / \mathrm{ha}$ Urea+300 kg/ha NPK 16-6-23 & 196.61 \\
$100 \mathrm{~kg} / \mathrm{ha}$ Urea+400 kg/ha NPK 16-6-23 & 161.02 \\
\hline
\end{tabular}

Table 9 shows the additional costs and additional revenue for Inpari 30 rice farming. The result showed that the fertilization $G$ treatment resulted in the highest total and additional revenue of Rp. 40.678.200 and Rp. 23.392.230. while fertilization of $E$ treatment resulted in the lowest total revenue and additional income of Rp. 22.185.930 and Rp. 4.899.960. The result of the calculation of value-added was shown in Table 10. The farm income analysis obtained by farmers can be calculated from the production results multiplied by the price of the farmer's product, while the farmer's income is the total income minus the costs incurred by the farmer. DNI, which is the marginal net income, is shown in table 10. Treatment $\mathrm{G}$ treatment produces the highest dNI of Rp. 21.686.230, following the $\mathrm{H}$ treatment $\mathrm{Rp}$. 13.281.430. The highest marginal rate of return $(R)$ is also obtained from the $\mathrm{G}$ treatment approximately 12.71 , following the D treatment approximately 7.31 .

Table 5. Total filled grain per panicle, empty grain per panicle, total grain per panicle, percent filled grain, and weight of 1000 Inpari 30 grains in Gili Timur Village, Kamal District, Bangkalan Regency

\begin{tabular}{|c|c|c|c|c|c|c|c|c|c|}
\hline \multirow{2}{*}{$\begin{array}{c}\text { No. } \\
1\end{array}$} & \multirow[t]{2}{*}{ Treatment } & \multicolumn{2}{|c|}{$\begin{array}{l}\text { Total filled } \\
\text { grain per } \\
\text { panicle }\end{array}$} & \multicolumn{2}{|c|}{$\begin{array}{l}\text { empty grain } \\
\text { per panicle }\end{array}$} & \multirow{2}{*}{$\begin{array}{r}\begin{array}{c}\text { total grain } \\
\text { per panicle }\end{array} \\
105.13\end{array}$} & \multicolumn{2}{|c|}{$\begin{array}{c}\text { percent filled } \\
\text { grain }\end{array}$} & \multirow{2}{*}{$\begin{array}{c}\begin{array}{c}\text { weight of } \mathbf{1 0 0 0} \\
\text { grains (gr) }\end{array} \\
27.77\end{array}$} \\
\hline & & 82.38 & $\mathrm{~b}$ & 22.75 & $\mathrm{a}$ & & 78.34 & $\overline{\mathrm{e}}$ & \\
\hline 2 & Standard (B) & 95 & $\mathrm{ab}$ & 15.62 & $\mathrm{~cd}$ & 110.62 & 85.55 & $\mathrm{~cd}$ & 28.53 \\
\hline 3 & 200 kg/ha NPK 16-6-23 (C) & 95.24 & $\mathrm{ab}$ & 19.22 & $a b$ & 114.47 & 83.01 & $\mathrm{~d}$ & 27.77 \\
\hline 4 & 300 kg/ha NPK 16-6-23 (D) & 103.36 & $\mathrm{ab}$ & 12.89 & de & 116.24 & 88.8 & $\mathrm{ab}$ & 26.75 \\
\hline 5 & 400 kg/ha NPK 16-6-23 (E) & 104.78 & a & 16.31 & bcd & 121.09 & 86.41 & $\mathrm{bc}$ & 26.5 \\
\hline 6 & 200 kg/ha Urea+200 kg/ha NPK 16-6-23 (F) & 107.96 & $\mathrm{a}$ & 14.55 & cde & 122.51 & 87.95 & $\mathrm{abc}$ & 27.6 \\
\hline 7 & 200 kg/ha Urea+300 kg/ha NPK 16-6-23 (G) & 115.73 & $\mathrm{a}$ & 11.84 & $\mathrm{e}$ & 127.58 & 90.7 & a & 27.27 \\
\hline 8 & 100 kg/ha Urea+400 kg/ha NPK 16-6-23 (H) & 106.02 & $\mathrm{a}$ & 17.27 & bc & 123.29 & 85.81 & bcd & 27.49 \\
\hline
\end{tabular}

\section{Discussion}

The primary soil analysis results indicate that this soil is dominated by negative charges that are thought to come from clay minerals. This negative charge causes the soil to have a high affinity for binding cations and releasing anions from the sorption complex so that they become available forms. This can also be seen from the very high $\mathrm{CEC}$ for the land. The total $\mathrm{N}$ content of the soil is also in the low category, so the addition of NPK fertilizer was estimated to improve and increase rice growth (Irfan et al., 2016).
Fertilization dosage treatment did not affect plant height at harvest time (Table 3 ). This is because the Urea with $46 \%$ Nitrogen and 16-6-23 NPK content with $16 \%$ Nitrogen content can provide the most nitrogen supply, $140 \mathrm{~kg} / \mathrm{ha}$ (Mawardiana et al., 2013). $\mathrm{N}$ fertilizer efficiency is only about $30 \%$, while the rest is lost through volatilization, denitrification, and leaching, causing the development of relatively uniform plant height in the generative phase.

Another parameter that also determines the yield of rice is the number of productive seedlings. The number 
of productive seedlings is the seedling number that produces panicles. Table 4 shows that the treatment of fertilization doses had no significant effect on the number of productive seedlings of Inpari 30 rice. A higher fertilizer dose needs to be implemented to plants because nutrients are lost through volatilization, denitrification, and leaching and absorbed in soil colloids into unsustainable forms available to plants.

The result of fertilization treatment of NPK 16-6-23 as much as $300,400 \mathrm{~kg} / \mathrm{ha}$, and $300 \mathrm{~kg}+200 \mathrm{~kg} / \mathrm{ha}$ Urea resulted in low panicle length (Tab. 4). The application of low $\mathrm{P}$ concentrations causes rice plants not to produce panicles, even though the total $\mathrm{P}$ in the soil is very high (Tab. 2). This is because the soil $\mathrm{pH}$ is somewhat alkaline, $\mathrm{P}$ elements are bound in the form of $\mathrm{Ca}-\mathrm{P}$ and Mg-P. The low content of soil organic matter makes this bound $\mathrm{P}$ element challenging to release into available forms for plants. The addition of organic matter is needed to block the positive charge from the adsorption complex to be rereleased.

Fertilization treatment affects panicle length. Fertilization treatment NPK 16-6-23 singly at $300 \mathrm{~kg} / \mathrm{ha}$, $400 \mathrm{~kg} / \mathrm{ha}$ or combined with Urea $200 \mathrm{~kg} / \mathrm{ha}$ was able to produce higher panicle length than other treatments (Tab. 4). Not all rice seedlings succeeded in forming panicles which later produced filled grains. The genetic properties of plants and the growing environment, including nutrient adequacy, pests, and diseases and environmental stress, affect yield (Huber et al., 2012). In the seedling formation phase, sufficient nitrogen is needed, while in the panicle formation phase, the $\mathrm{P}$ element is more dominant in the flowering process to seed filling (translocation of photosynthate products) to the ovules (Susanto \& Sirappa, 2014)

The NPK 16-6-23 fertilizer affects filled and hollow grain, and the percentage of filled grain, but does not affect the total amount of grain and weight of 1000 seeds (Tab. 5). These phenomena indicate the influence of nitrogen in chlorophyll formation. Hence, the photosynthesis rate also increases. High plant assimilation in the generative phase allows translocation to the zinc area, resulting in the optimal formation and filling of seeds and leading to optimal production of grain/clumps (Gardner et al., 1991; Pirngadi, et al., 2007).

In addition to Nitrogen, Potassium also plays a role in filling well-filled seeds and transporting the photosynthetic process in leaves to other plant parts. More than that, they regulate turgor pressure, strengthens cell walls, activates enzymes in all plant metabolic processes, delays leaf aging, increases the amount of grain pithy, and brings down the void (Rajendran, et al., 2009; Gani, 2009). In this study, the need for potassium element was also fulfilled from NPK 16-6-23 fertilizer, which had a higher $\mathrm{K}$ content than in NPK 15-15-15, $23 \%$.

Fertilization treatment at a dose of $200 \mathrm{~kg} / \mathrm{ha}$ Urea + $300 \mathrm{~kg} / \mathrm{ha}$ NPK 16-6-23 (G treatment) resulted in low unhulled rice, which was not significantly different from the $300 \mathrm{~kg} / \mathrm{ha}$ NPK 16-6-23 (D treatment), but significantly different than without fertilization and 200 kg/ha NPK 16-6-23 (C treatment) (Tab. 5).

Table 7. The costs and income of farming and analysis results of $\mathrm{B} / \mathrm{C}$ ratio of Inpari 30 rice plants with control treatment, recommendation, a combination of $200 \mathrm{~kg} / \mathrm{ha}$ NPK 16-6-23 and combination treatment $300 \mathrm{~kg} / \mathrm{ha}$ NPK 16-6-23 in Gili Timur village, District Kamal, Bangkalan Regency

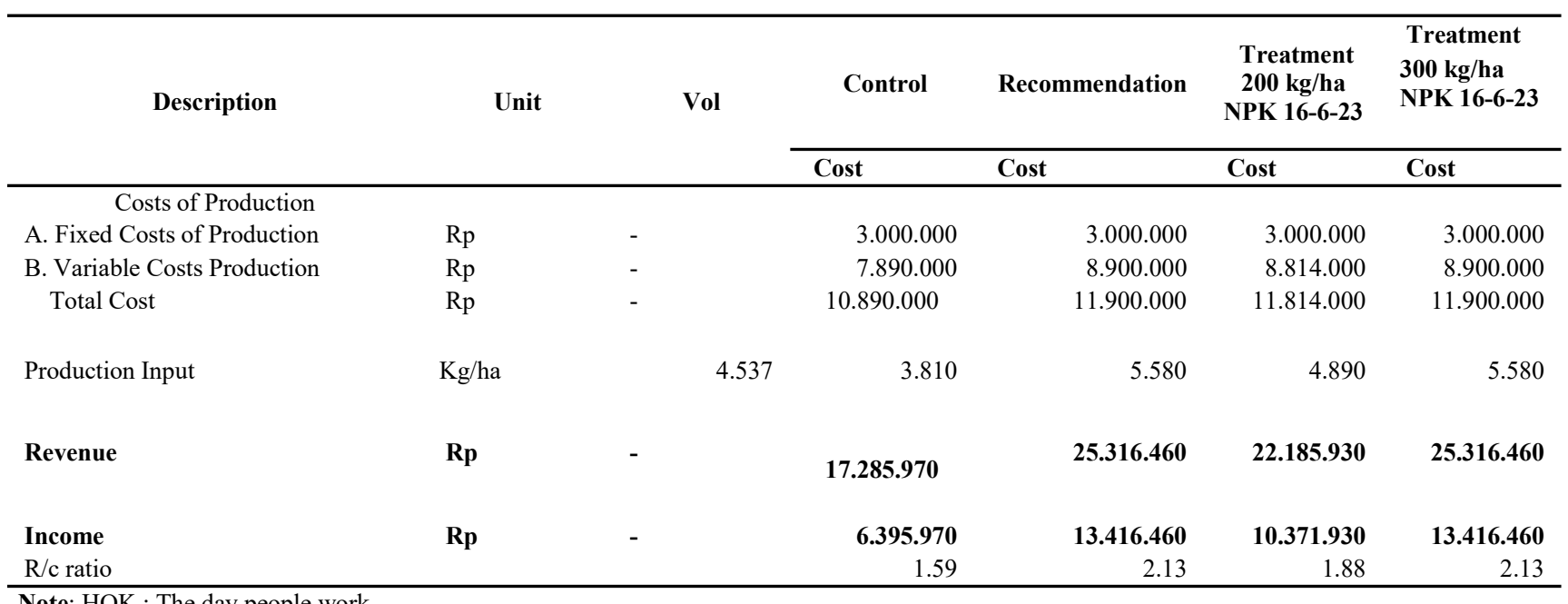

Note: HOK : The day people work 
Table 8. The costs and income of farming and analysis results of $\mathrm{B} / \mathrm{C}$ ratio of rice Inpari 30 plants with a combination treatment of $400 \mathrm{~kg} / \mathrm{ha} \mathrm{NPK}$ 16-6-23, $200 \mathrm{~kg} / \mathrm{ha}$ Urea $+200 \mathrm{~kg} / \mathrm{ha}$ NPK 16-6-23, $200 \mathrm{~kg} / \mathrm{ha}$ Urea $+300 \mathrm{~kg} / \mathrm{ha} \mathrm{NPK} \mathrm{16-6-23} \mathrm{and} \mathrm{a} \mathrm{combination} \mathrm{of} \mathrm{treatment} 100 \mathrm{~kg} / \mathrm{ha}$ Urea +400 $\mathrm{kg} / \mathrm{ha}$ NPK 16-6-23 in the village of Gili Timur, Kamal District, Bangkalan Regency

\begin{tabular}{|c|c|c|c|c|c|c|}
\hline Description & Unit & Vol & $\begin{array}{l}\text { Treatment } \\
400 \mathrm{~kg} / \mathrm{ha} \text { NPK } \\
16-6-23\end{array}$ & $\begin{array}{l}\text { Treatment } \\
200 \mathrm{~kg} / \mathrm{ha} \\
\text { Urea+200 kg/ha } \\
\text { NPK 16-6-23 }\end{array}$ & $\begin{array}{l}\text { Treatment } \\
200 \mathrm{~kg} / \mathrm{ha} \\
\text { Urea+300 } \\
\text { kg/ha NPK 16- } \\
\text { 6-23 }\end{array}$ & $\begin{array}{l}\text { Treatment } \\
100 \text { kg/ha Urea }+400 \\
\text { kg/ha NPK 16-6-23 }\end{array}$ \\
\hline & & & Cost & Cost & Cost & Cost \\
\hline
\end{tabular}

Costs of Production

\begin{tabular}{|c|c|c|c|c|c|c|}
\hline A. Fixed Costs of Production & $\mathrm{Rp}$ & - & 3.000 .000 & 3.000 .000 & 3.000 .000 & 3.000 .000 \\
\hline B. Variable Costs Production & $\mathrm{Rp}$ & - & 9.738 .000 & 9.134 .000 & 9.596 .000 & 9.898 .000 \\
\hline Total Cost & $\mathrm{Rp}$ & - & 12.738 .000 & 12.134 .000 & 12.596 .000 & 12.898 .000 \\
\hline Production Input & $\mathrm{Kg} / \mathrm{ha}$ & 4.537 & 7.050 & 6.620 & 7.290 & 6.660 \\
\hline Revenue & $\mathrm{Rp}$ & - & 31.985 .850 & 30.034 .940 & 33.074 .730 & 30.216 .420 \\
\hline Income & $\mathrm{Rp}$ & - & 19.247 .850 & 17.900 .940 & 20.478 .730 & 17.318 .420 \\
\hline $\mathrm{R} / \mathrm{C}$ ratio & & & 2.51 & 2.48 & 2.63 & 2.34 \\
\hline
\end{tabular}

Note: HOK : The day people work

Table 9. The additional costs and additional receipts for rice Inpari 30 farming

\begin{tabular}{|c|c|c|c|c|}
\hline Components & $\begin{array}{l}\text { Total Cost } \\
\text { (Rp) }\end{array}$ & $\begin{array}{l}\text { Additional } \\
\text { costs(Rp) }\end{array}$ & $\begin{array}{l}\text { Total receipts } \\
\text { (Rp) }\end{array}$ & $\begin{array}{l}\text { Additional receipts } \\
\text { (Rp) }\end{array}$ \\
\hline Without Fertilizer & 7.890 .000 & - & 17.285 .970 & \\
\hline Recommendation & 8.900 .000 & 1.010 .000 & 25.316 .460 & 8.030 .490 \\
\hline $200 \mathrm{~kg} / \mathrm{ha}$ NPK 16-6-23 & 8.814 .000 & 924.000 & 22.185 .930 & 4.899 .960 \\
\hline $300 \mathrm{~kg} / \mathrm{ha}$ NPK 16-6-23 & 9.276 .000 & 1.386 .000 & 28.809 .950 & 11.523 .980 \\
\hline $400 \mathrm{~kg} / \mathrm{ha}$ NPK 16-6-23 & 9.738 .000 & 1.848 .000 & 31.985 .850 & 14.699 .880 \\
\hline $200 \mathrm{~kg} / \mathrm{ha}$ Urea+200 kg/ha NPK 16-6-23 & 9.134 .000 & 1.244 .000 & 25.222 .200 & 7.936 .230 \\
\hline $200 \mathrm{~kg} / \mathrm{ha}$ Urea+300 kg/ha NPK 16-6-23 & 9.596 .000 & 1.706 .000 & 40.678 .200 & 23.392 .230 \\
\hline $100 \mathrm{~kg} / \mathrm{ha}$ Urea+400 kg/ha NPK 16-6-23 & 9.890 .000 & 2.000 .000 & 32.567 .400 & 15.281 .430 \\
\hline
\end{tabular}

Table 10. The value added calculation

\begin{tabular}{lrr}
\hline Treatment & dNI \\
\hline Recommendation & R & 7.020 .490 \\
$200 \mathrm{~kg} / \mathrm{ha} \mathrm{NPK} \mathrm{16-6-23}$ & 3.975 .960 & 4.3 \\
$300 \mathrm{~kg} / \mathrm{ha} \mathrm{NPK} \mathrm{16-6-23}$ & 7.31 \\
$400 \mathrm{~kg} / \mathrm{ha} \mathrm{NPK} \mathrm{16-6-23}$ & 6.95 \\
$200 \mathrm{~kg} / \mathrm{ha}$ Urea+200 kg/ha NPK 16-6-23 & 5.37 .980 \\
$200 \mathrm{~kg} / \mathrm{ha}$ Urea+300 kg/ha NPK 16-6-23 & 12.851 .880 \\
$100 \mathrm{~kg} / \mathrm{ha}$ Urea+400 kg/ha NPK 16-6-23 & 6.692 .230 \\
\hline
\end{tabular}

The percentage of filled grain in the $G$ treatment was not significantly different from $\mathrm{D}$ and $\mathrm{F}$ treatments. All of them produced higher filled grain that significantly different from the control and standard treatment. Based on statistical analysis. there was no significant effect on the weight of 1000 seeds with a value range of 26.5 $28.53 \mathrm{~g}$ (Tab. 5). This result follows the Inpari 30 variety description, which has an average weight of 1000 seeds, namely $27 \mathrm{~g}$ (Balai Besar Padi, 2015). The weight of 1000 grains is influenced by the shape and size of each variety's grain morphology. The $\mathrm{G}, \mathrm{D}$, and F treatments yield a higher percentage of filled grain than other treatments. These results are consistent with the previous study by Chen et al. (2020) that the application of controlled-release urea (CRU) considered an effective $\mathrm{N}$ fertilizer and significantly increases yield component analysis. The greater rice grain yield in response to $\mathrm{N}$ fertilizer was mainly attributed to the number of panicles per $\mathrm{m} 2$, which increased in the fertilized treatments compared to the treatment without $\mathrm{N}$ application.

Figure 1 shows that the $G$ treatment gives a high yields, followed by $\mathrm{E}$ treatment, suggesting the optimal dose implementation of $200 \mathrm{~kg} / \mathrm{ha}$ Urea and $300 \mathrm{~kg} / \mathrm{ha}$ NPK 16-6-23, and $400 \mathrm{~kg} / \mathrm{ha}$ NPK 16-6-23. The N content is low in the sampling site (Tab. 2). Hence, the addition of $200 \mathrm{~kg} / \mathrm{ha}$ of urea fertilizer and $300 \mathrm{~kg} / \mathrm{ha} 16-$ 6-23 NPK compound fertilizer will increase yields up to 7.29 tonnes/ha. In contrast, the lowest yield was obtained 
from the treatment without fertilizer, followed by 200 $\mathrm{kg} / \mathrm{ha}$ NPK 16-6-23 and standard treatment. The fertilizers compound with $15 \%$ Nitrogen $(\mathrm{N}), 15 \%$ Phosphorus (P), 15\% Potassium (K), and the addition of $200 \mathrm{~kg} / \mathrm{ha}$ Urea can compete with NPK compound fertilizers with $16 \%$ Nitrogen $(\mathrm{N})$ nutrient content, $6 \%$ Phosphorus (P) and 23\% Potassium (K) as much as 200 $\mathrm{kg} / \mathrm{ha}$ without the addition of urea. Thus, the effectiveness of NPK 16-6-23 compound fertilizer was higher, which also indicated by its RAE value of more than $100 \%$. The highest RAE value was found in the $\mathrm{G}$ treatment, reaching $196.61 \%$ (Tab. 6).

The farming business analysis shows that the fertilizer dosage $G$ treatment offers greater profits than other treatment, although the production costs incurred were higher (Tab. 8). Control treatment resulted in an $\mathrm{R} / \mathrm{C}$ ratio of 1.19 . The control treatment incurs the smallest cost of Rp. 7.890 .000 and a profit of Rp. 9.395.970. Treatment recommendation obtained an $\mathrm{R} / \mathrm{C}$ ratio of 1.89 , incurred a cost of $\mathrm{Rp} .8 .900 .000$ and a profit of Rp. 16.416.460. The $\mathrm{C}$ treatment resulted in an $\mathrm{R} / \mathrm{C}$ ratio of 1.51 , which cost Rp. 8.814 .000 with a profit of Rp. 13.371.930. While the D Treatment resulted in an $\mathrm{R} / \mathrm{C}$ ratio of 1.84 , which cost Rp. 8.900 .000 with a profit of Rp. 16.416.460.

The E, F, G, and $\mathrm{H}$ treatments resulted in an $\mathrm{R} / \mathrm{C}$ ratio of $2.28,1.76,3.23$, and 2.29 , respectively. The G treatment with the highest production cost of $\mathrm{Rp}$. 9.596.000 were able to obtain the highest profit of Rp. 31.082.200, followed by $\mathrm{H}$ and $\mathrm{E}$ treatment with a production cost of Rp. 9.898.000 and Rp. 9.738.000 respectively. According to Pudaka et al. (2018), the fertilizers should meet the following recommendations to obtain the maximum yield. The results of this study are similar to previous study (Indah et al., 2015), which recommended the use of fertilizers in rice farming with $300 \mathrm{~kg} / \mathrm{ha}$ urea, $250 \mathrm{~kg} / \mathrm{ha} \mathrm{NPK}$, and SP36 $125 \mathrm{~kg} / \mathrm{ha}$. In contrast, another study reported that fertilizer did not significantly affect rice production in Subak Pacung Babakan Village, Mengwi District, Badung Regency (Dewi et al., 2012).

Partially rice Inpari 30 farming with those 8 treatments provide additional costs and affect additional farm receipts. An overview of the partial analysis of chili farming can be seen in table 9. Table 9 shows that the recommended treatment with an additional cost of Rp. 1.010.000 obtained an additional income of $\mathrm{Rp}$. 8.030.490 compared to control, with a reduction in additional costs by Rp. 924.000 (8.5\%), the additional income decreased by Rp. $4.899 .960(40 \%)$ in the C treatment compared to the recommended treatment. The $\mathrm{D}$ treatment incurred an additional cost of Rp. 1.386 .000 (37\%) and received an additional Rp. 11.523 .980 (43.5\%) compared to the recommended treatment. The E treatment incurred an additional cost of Rp. 1.848.000 $(83 \%)$ and received additional income of IDR $14.699 .880 \quad(83 \%)$ compared to the recommended treatment.

The $\mathrm{F}$ treatment incurred an additional cost of $\mathrm{Rp}$. $1.244 .000(23 \%)$ resulted in a decrease in additional income by $1.2 \%$, namely to $\mathrm{Rp} .7 .936 .230$ compared to recommended treatment. The $\mathrm{G}$ treatment incurred an additional cost of Rp. 1.706 .000 (69\%) and received additional income of Rp. 23.392 .230 (191\%) compared to the recommended treatment. The $\mathrm{H}$ treatment incurred an additional cost of Rp. 2.000 .000 (98\%) and received additional income of Rp. 15.281.430 (increased by 90\%) compared to the recommended treatment.

To obtain more comprehensive analysis, an added value is also calculated by recalculating the marginal net income (dNI) obtained from the marginal total revenue (dTR) minus the marginal cost of change (dVC). From the calculation results in Table 10, it is known that the $G$ treatment resulted in the highest DNI of 21,686,230 with an increase of marginal net income by $209 \%$ compared to dNI from the recommended treatment, R 12.71 . Followed by $\mathrm{H}$ and $\mathrm{E}$ treatment that obtained the $\mathrm{dNI}$ value of $13.281 .430(89 \%)$ and $12.851 .880(83 \%)$, respectively. In addition, the marginal rate of return is obtained from the comparison of marginal net income and the lowest marginal change costs produced by the treatment of $\mathrm{C}$ treatment and $\mathrm{F}$ treatment that produces $\mathrm{R}$ of 4.30 and 5.38, with the lowest marginal net revenues 3.975 .960 and 6.692.230, respectively. Thus, it can be seen that the two treatments have a lower marginal net income and marginal change costs than the recommended treatment.

In conclusion, The compound fertilizer NPK 16-6-23 is very influential on the productivity of Inpari 30 rice plants. By combining $200 \mathrm{~kg} / \mathrm{ha}$ of urea fertilizer with NPK 16-6-23 doses of $300 \mathrm{~kg} / \mathrm{ha}$ on rice, plants can provide high yields (7.29 t/ha). Thus, NPK 16-6-23 unbalanced compound fertilizer can substitute for NPK 15-15-15 balanced compound fertilizer. The application of $200 \mathrm{~kg} / \mathrm{ha}$ Urea fertilizer combined with $300 \mathrm{~kg} / \mathrm{ha}$ NPK 16-6-23 is more profitable for farmers because it produces the highest $\mathrm{RAE}$ and $\mathrm{R} / \mathrm{C}$ ratios, incurs an additional cost of $69 \%$ but earns an additional income of $191 \%$ compared to treatment recommendation. Treatment of $200 \mathrm{~kg} / \mathrm{ha}$ Urea $+300 \mathrm{~kg} / \mathrm{ha}$ NPK 16-6-23 also produced the highest marginal net income with an increase in marginal net income by $209 \%$ compared to the marginal net income of recommended treatment the resulting increase in marginal return was $83 \%$.

\section{Acknowledgement}

We declared that all authors are the main contributor to this paper.

\section{References}

Abdulrachman, S., Sembiring, H., \& Suyamto. (2009). Pemupukan Tanaman Padi. Balai Besar Penelitian Tanaman Padi.

Azis, F.N., Aisyawati, L., \& Tata, H. R. (2018). Terhadap Pertumbuhan Dan Hasil Padi Kultivar Cibogo Di Magetan. Prosiding Seminar Nasional Mewujudkan Kedaulatan Pangan Melalui Penerapan Inovasi Teknologi Pertanian Spesifik Lokasi Pada Kawasan Pertanian, 483-493.

Badan Pusat Statistik Provinsi Jawa Timur. (2016). Indikator Pertanian Provinsi Jawa Timur 2016. Badan Pusat Statistik Provinsi Jawa Timur.

Chen, Z., Wang, Q., Ma, J., Zou, P., \& Jiang, L. (2020). Impact of controlled-release urea on rice yield, nitrogen use efficiency and soil fertility in a single rice cropping system. Scientific Reports, 10(1), 1-10.

Dewi, I., Suamba, I., \& Ambarwati, I. (2012). Analisis Efisiensi Usahatani Padi Sawah (Studi Kasus Di Subak Pacung Babakan, 
Kecamatan Mengwi, Kabupaten Badung). Journal of Agribusiness and Agritourism, 1(1), 1-10.

Gani, A. (2009). Keunggulan Pupuk Majemuk NPK Lambat Urai untuk Tanaman Padi Sawah. Penelitian Tanaman Pangan, 28(3), $148-157$.

Gardner, F.P., R.B. Pearce, R.L. Mitchel. (1991). Fisiologi Tanaman Budidaya. UI Press, Jakarta. $728 \mathrm{p}$

Gomez, K. A., A.A. Gomez. (2007). Prosedur Statistik untuk Penelitian Pertanian. Universitas Indonesia Press. Jakarta

Hartatik, W., \& Widowati, L. R. (2015). Pengaruh Pupuk Majemuk NPKS dan NPK terhadap Pertumbuhan dan Hasil Padi Sawah pada Inceptisol Effect of Compound fertilizer NPKS and NPK on Rice Growth and Yield on Inceptisol. Penelitian Pertanian Tanaman Pangan, 34(3), 175-186.

Huang, J., He, F., Cui, K., Buresh, R. J., Xu, B., Gong, W., \& Peng, S. (2008). Determination Of Optimal Nitrogen Rate For Rice Varieties Using A Chlorophyll Meter. Field Crops Research, 105(1-2), 70-80. https://doi.org/10.1016/j.fcr.2007.07.006

Huber, D., Römheld, V., \& Weinmann, M. (2012). Relationship between Nutrition, Plant Diseases and Pests. In Marschner's Mineral Nutrition of Higher Plants (pp.283-298)

Indah, L. S. M., Zakaria, W. A., \& Prasmatiwi, F. E. (2015). Analisis Efisiensi Produksi dan Pendapatan Usahatani Padi Sawah Pada Lahan Irigasi Teknis Dan Lahan Tadah Hujan Di Kabupaten Lampung Selatan. Jurnal Ilmu-Ilmu Agribisnis, 3(3), 260-267.

Irfan, M., Memon, M. S., Shah, J. A., \& Abbas, M. (2016). Application of Nitrogen and Phosphorus in Different Ratios To Affect Paddy Yield, Nutrient Uptake and Efficiency Relations in Rice (Oryza Sativa L.). J. Environ. Agric, 1(2), 79-86.

Jamil, A., Satoto, Sasmita, P., Guswara, A., \& Suharna. (2015). Deskripsi Varietas Unggul Baru Padi. Balai Besar Penelitian Tanaman Padi, Badan Penelitian dan Pengembangan Pertanian Kementerian Pertanian.

Juanda, B. R. (2016). Peningkatan Produksi Padi Melalui Potensi Dan Pengembangan Wilayah Produksi Benih Unggul di Propinsi Aceh. Jurnal Penelitian Agrosamudra, 3(2), 72-80.

Mahmood, F., Khan, I., Ashraf, U., Sahzad, T., Hussain, S., Shahid, M., Abid, M. and Ullah, S. (2017). Effects of organic and inorganic manures on maize and their residual impact on soil physico-chemical properties. Journal of Soil Science and Plant Nutrition, 17(1), 22-32.

Malhotra, H., Vandana, Sharma, S., \& Pandey, R. (2018). Phosphorus Nutrition: Plant Growth in Response to Deficiency and Excess.
In Plant Nutrients and Abiotic Stress Tolerance (Issue July, pp. 171-190). Research Institute India.

Marchezan C., Ferreira, P. A. A., Silva, L. S., Bacca, A., Krug, A. V., Nicoloso, F. T., Tarouco, C. P., Tiecher, T. L., Brunetto, G., \& Ceretta, C. A. (2020). Nitrogen Availability And Physiological Response Of Corn After 12 Years With Organic And Mineral Fertilization. Journal of Soil Science and Plant Nutrition 20 (1), 979-989.

Mawardiana, Sufardi, \& Husen, E. (2013). Pengaruh Residu Biochar dan Pemupukan NPK terhadap Sifat Kimia Tanah dan Pertumbuhan Serta Hasil Tanaman Padi Musim Tanam Ketiga. Jurnal Manajemen Sumber Daya Lahan, 2(3), 255-260

Pirngadi, K., Toha, H. M., \& Nuryanto, B. (2007). Pengaruh Pemupukan N Terhadap Pertumbuhan dan Hasil Padi Gogo Dataran Sedang. Apresiasi Hasil Penelitian Padi, 325-338.

Pudaka, D. L., Rusdarti, \& Prasetyo, P. E. (2018). Efficency Analysis of Rice Production and Farmers' Income in Sengah Temila District Landak Regency. Journal of Economic Education, 7(1), 31-38.

Rajendran, C., Hepziba, S. J., Ramamoorthy, K. (2009). Nutritional and Physiological Disorders in Crop Plants. Scientific Publishers. India

Soekartawi. (2002). Analisis Usahatani. UI Press, Jakarta. 110p

Soha, M. E. D. (2014). The partial budget analysis for sorghum farm in Sinai Peninsula, Egypt. Annals of Agricultural Sciences, 59(1), $77-81$.

Suriadikarta, D.A., Setyorini, D. \& Hartatik, W. (2004). Petunjuk Teknis Uji Mutu dan Efektifitas Pupuk Alternatif Anorganik. Balai Penelitian Tanah, Bogor. 50p

Susanto, Andriko \& Sirappa, M. (2015). Assessment of Indigenous N, $\mathrm{P}$ and K Supply for Rice Site Specific Nutrient Management in Buru Regency. Journal of Tropical Soils 19(3), 151-159.

Wihastuti, W., Sujaya, D. H., \& Hardiyanto, T. (2017). Analisis Usahatani Padi Organik (Studi Kasus pada Kelompok Tani Kelapa Herang di Desa Setiawaras Kecamatan Cibalong Kabupaten Tasikmalaya). Jurnal Ilmiah Mahasiswa Agroinfo Galuh, 4(3), 388-395.

Wildayana, E., \& Armanto, M. E. (2019). The Role of Subsidized Fertilizers on Rice Production and Income of Farmers in Various Land Typologies. Jurnal Ekonomi Pembangunan: Kajian Masalah Ekonomi Dan Pembangunan, 20(1), 100-107. 